\title{
The Real Race between Time and Invention of Covid 19 Vaccine
}

\author{
Rajeev Shah ${ }^{1 *}$ and Reena Mehta ${ }^{2}$ \\ ${ }^{1}$ Professor and Head, Microbiology Department, Pacific Medical College and Hospital, \\ Pacific University, Udaipur, India \\ ${ }^{2}$ Expert in Genetics and Cancer/Expert in DNA Technology, University of New South \\ Wales, Australia \\ *Corresponding Author: Rajeev Shah, Professor and Head, Microbiology \\ Department, Pacific Medical College and Hospital, Pacific University, Udaipur, India.
}

\author{
Received: May 16, 2020 \\ Published: May 28, 2020
}

(C) All rights are reserved by Rajeev Shah and Reena Mehta.

Keywords: Covid-19 Vaccine; Corona Virus; Covid-19; Corona Pandemic

Covid-19 pandemic shocks and locks whole world at the end of 2019 and 2020. Maximum death occurred in USA followed by Italy and Spain. Here discussion and analysis have been focused on various types of vaccines of Corona virus on basis of its spike antigen $\mathrm{S}$ and its corresponding human ACE2 receptor on cells. The ultimate target of all types of vaccines is to prevent binding of ACE2 receptor to $S$ antigen of corona, except long acting interferons. The interferons are natural antiviral substances produced by virus infected mammalian cells and are of three types $\alpha, \beta$ and $\delta$. The main sources of the latest information of Covid-19 vaccination has been internet websites and social net working sites like whatsApp and facebook etc.

A vaccine is a type of preparation of body to fight against particular pathogen before particular infection really body come across or real fight starts, aimed at stimulating the body's immune system to fight against that infectious pathogens, like bacteria and viruses. They are, according to the World Health Organization, "one of the most effective ways to prevent diseases." Vaccines are a really clever fake-out. They make the body think it's infected so it stimulates this immune response. It resembles to some extent to mock drill of body's immune system to fight against particular pathogen.

Vaccines can be classify first into two groups, 1 . Live attenuated vaccines 2 . Inactivated vaccines which can be divided into A. Whole killed vaccines B. Subunit vaccines (also called acellular vaccines), which again further divided into I. Toxoid Vaccines II Conjugate vaccines III Recombinant vaccines.

Among all above types, toxoid vaccine is out of consideration, as Covid-19 is a virus. According to me the easiest type to prepare is whole killed vaccines but with Covid-19, while killing or inactivating process, the desired antigenicity of spike antigen $\mathrm{S}$ should have to be kept intact. The method of whole killed vaccine developing for Covid-19 by this method, one has to find out the method of inactivation in which Covid 19's spike antigen S should remains unaffected. Even though killed vaccine's effect does not last long, it serves best in such urgent situations.

Recently on $28^{\text {th }}$ April, there is a video on facebook that Oxford University, London claimed of finding out live attenuated vaccine which had been on trial basis on 800 human volunteers and they ordered Serum India company located near Poona, which have the capacity of producing 1.5 billion vaccines every year. They will prepare about 50 - 100 million doses of vaccine in the month of September 2020. Oxford Covid-19 vaccine works on monkeys may hit market by September 2020. If this vaccine will found satisfactory, it would be the fastest vaccine invented ever, as usually five to six years are required in such invention, The cost wise also it will be also very cheap, it will cost about 0.5 cent per vaccine. In India many big companies are there with large capacity of production of vaccines. The other claims of Germany and UK, the vaccine developed from chimpanzee's Corona virus is ahead of other type as now they got permission of even testing on human volunteers. Bharat Biotech, the other vaccine producing company at Hyderabad claim to prepare 300 million doses at the end of the year 2020. Other well known companies are Indian Immunologicals and Zydus. The Zydus explores biological route to treat Covid-19 with long acting interferons. Israeli defense lab claimed totally new approach of vaccine, in which rather than injecting a pathogen's antigen into human body, body has been given genetic code needed to produce that antigen itself.

Israel claims this unique vaccine production requires minimum of nine months. The report of Arab news, quoting Italian news agency ANSA, claimed that company Takis isolated antibodies in mice which blocked virus from infecting human cells, which according to us should be not consider as vaccine but is the method of passive immunization and will be useful only in treatment but 
not for prophylaxis. Australia also claimed to develop monoclonal antibodies but by different technique but is also not vaccine candidate like Italian.

Even though whole world's scientists are working on the finding out of treatment as well as vaccine against Covid-19, but not succeeded till 8th May 2020. So, looking to all above data we anticipate Covid-19 vaccine will be available in about one year or so. Thus, until non availability of effective neither vaccine nor treatment, social distancing and lockdown only can control the spread, which in turn can decrease morbidity and mortality in the whole globe.

\section{Assets from publication with us}

- Prompt Acknowledgement after receiving the article

- Thorough Double blinded peer review

- Rapid Publication

- Issue of Publication Certificate

- High visibility of your Published work

Website: https://www.actascientific.com/

Submit Article: https://www.actascientific.com/submission.php

Email us: editor@actascientific.com

Contact us: +919182824667 